Terakreditasi: SK No.: 60/E/KPT/2016

Website : http://ejournal.undip.ac.id/index.php/reaktor/

Reaktor, Vol. 16 No. 4, Desember Tahun 2016, Hal. 199-206

\title{
Peningkatan Produksi Gula Pereduksi dari Tandan Kosong Kelapa Sawit dengan Praperlakuan Asam Organik pada Reaktor Bertekanan
}

\author{
Fahriya Puspita Sari*), Nissa Nurfajrin Sholihat, Sita Heris Anita, Fitria, \\ dan Euis Hermiati \\ Pusat Penelitian Biomaterial - LIPI \\ J1. Raya Bogor Km 46 Cibinong, Bogor, 16911, Indonesia \\ Tel. 021-87914511; Fax. 021-87914510 \\ ${ }^{*}$ Penulis korespondensi: fahr006@lipi.go.id
}

\begin{abstract}
ENHANCEMENT OF REDUCING SUGAR PRODUCTION FROM OIL PALM EMPTY FRUIT BUNCH BY PRETREATMENT USING ORGANIC ACID IN PRESSURIZED REACTOR. Organic acids are potential to create more environmentally friendly process in the pretreatment of lignocellulosic biomass for bioethanol production. This study was aimed to investigate the influence of organic acid pretreatment in reducing sugar production in a pressurized reactor with various resident times and temperatures on enzymatic hydrolysis of OPEFB. Two different organic acids (maleic acid and oxalic acid) were used in the pretreatment of oil palm empty fruit bunch (OPEFB) using a pressurized reactor. Factorial design using three different temperatures (170, 180, and $\left.190^{\circ} \mathrm{C}\right)$ and four resident times $(15,30,45$, and $60 \mathrm{~min})$ were employed, followed by enzymatic hydrolysis. Each condition conducted two repetitions. Analysis was conducted on the reducing sugar that was produced after saccharification by means of the severity factor of each pretreatment condition. Maleic acid showed higher reducing sugar yield with lower severity factor than oxalic acid with the same operating conditions. The highest yield of reducing sugars (80.84\%) was obtained using maleic acid at 170 for 60 minutes with severity factor of 1.836 .
\end{abstract}

Keywords: bioethanol; organic acid pretreatment; pressurized reactor; severity factor; oil palm empty fruit bunches;

Abstrak

Asam organik berpotensi dalam membantu proses praperlakuan dari biomassa lignoselulosa untuk memproduksi bioetanol yang ramah lingkungan. Penelitian ini bertujuan untuk mengetahui pengaruh asam organik, suhu dan waktu operasi terhadap produksi gula pereduksi dengan reaktor bertekanan pada tandan kosong kelapa sawit. Dua asam organik yang berbeda yaitu asam oksalat dan asam maleat digunakan untuk proses praperlakuan tandan kosong kelapa sawit (TKKS) dengan bantuan reaktor bertekanan. Dalam proses praperlakuan digunakan tiga suhu yang berbeda yaitu suhu 170, 180, dan $190^{\circ} \mathrm{C}$ dan empat waktu operasi 15, 30, 45, dan 60 min yang dilanjutkan dengan proses hidrolisis enzimatis. Setiap kondisi dilakukan dua kali pengulangan. Analisa yang digunakan adalah analisa uji gula pereduksi dan severity factor pada kondisi tiap praperlakuan. Asam maleat menunjukkan hasil yang lebih baik dengan severity factor yang lebih rendah dibandingkan menggunakan asam oksalat dengan kondisi operasi yang sama. Hasil yang didapatkan menunjukkan bahwa praperlakuan tandan kosong kelapa sawit dengan bantuan reaktor bertekanan memiliki rendemen gula pereduksi optimum sebesar 80,84\% dengan menggunakan asam maleat pada suhu $170^{\circ} \mathrm{C}$ selama 60 menit dengan severity factor sebesar 1,836 . 
Kata kunci: bioetanol; praperlakuan asam organik; reaktor bertekanan; severity factor; tandan kosong kelapa sawit.

How to Cite This Article: Sari, F.P., Sholihat, N.N., Anita, S.H., Fitria, dan Hermiati, E., (2016), Peningkatan Produksi Gula Pereduksi dari Tandan Kosong Kelapa Sawit dengan Praperlakuan Asam Organik pada Reaktor Bertekanan, Reaktor, 16(4), 199-206, http://dx.doi.org/10.14710/reaktor.16.4.199-206

\section{PENDAHULUAN}

Tandan kosong kelapa sawit (TKKS) merupakan sumber lignoselulosa hasil samping dari industri minyak kelapa sawit. Produksi kelapa sawit di Indonesia pada tahun 2015 mencapai 29 juta ton per tahun dan menghasilkan limbah TKKS sebanyak 22$23 \%$ dari setiap ton produksi kelapa sawit (Direktorat Jenderal Perkebunan, 2016). Limbah tandan kosong kelapa sawit menjadi masalah terhadap lingkungan dan bernilai ekonomi rendah. Sebelumnya, TKKS digunakan sebagai bahan bakar uap pada insinerasi pabrik dan abu yang dihasilkan digunakan sebagai pupuk (Yusoff, 2006). Namun, proses pembakaran tersebut menyebabkan terbentuknya emisi dan asap yang berwarna putih. Saat ini sebagian besar TKKS dijadikan sebagai kompos di area perkebunan (Mohammad dkk., 2012) dan budidaya jamur (Kerdsuwan dan Laohalidanond, 2011). Walaupun cara tersebut mampu mengurangi limbah TKKS, akan tetapi perlu dilakukan pengembangan dalam pemanfaatan TKKS agar lebih optimal, menguntungkan, dan ramah lingkungan, seperti bioetanol.

Biomassa lignoselulosa memiliki potensi yang sangat besar sebagai bahan alternatif dalam produksi bioetanol sehingga dapat memenuhi kebutuhan energi dunia. Menurut Kim dan Dale (2004) bioetanol yang dapat diproduksi dari biomassa lignoselulosa mencapai 442 milyar liter dan total dari residu dan limbah hasil pertanian dapat memproduksi 491 milyar liter bioethanol per tahun, dimana 16 kali lebih tinggi dibandingan dengan bioetanol yang diproduksi di dunia saat ini. Konversi biomassa lignoselulosa menjadi biofuel dapat memenuhi kebutuhan energi dan berpotensi dalam mengurangi emisi gas hingga $86 \%$ jika dibandingkan dengan bahan bakar fosil (Wang dkk., 2007). Bahan lignoselulosa memiliki struktur yang kompleks dimana struktur mikro dari dinding sel merupakan lignin dan matriks polisakarida yang sebagian besar mengandung selulosa dan hemiselulosa. Struktur tersebut membentuk suatu ikatan silang dan dan berikatan kuat dengan lignin. Struktur lignoselulosa yang sangat kompleks dari biomassa mengakibatkan akses enzim dan mikroba menjadi terhambat (Pu dkk., 2013).

Praperlakuan merupakan langkah pertama dalam produksi bioetanol untuk memecah struktur lignoselulosa yang nantinya akan berpengaruh pada besarnya rendemen gula pereduksi yang dihasilkan pada saat hidrolisis (Hendriks dan Zeeman, 2009). Tujuan dari praperlakuan adalah meningkatkan luas permukaan dan porositas pada biomassa, mengurangi kristalinitas pada selulosa, dan memecah struktur heterogen dari bahan lignoselulosa. Akan tetapi, degradasi gula akan terjadi selama proses praperlakuan sehingga perlu dicari kondisi dimana terjadi keseimbangan antara pembentukan inhibitor yang rendah dan tingginya tingkat pemecahan substrat agaroptimasi proses praperlakuan menjadi efisien (Talebnia dkk., 2010).

Beberapa proses dalam produksi bioetanol dari bahan lignoselulosa antara lain praperlakuan, hidrolisis enzimatik, fermentasi, dan pemisahan produk/distilasi (Sarkar dkk., 2012). Proses hidrolisis enzimatik merupakan proses hidrolisis yang mampu menghasilkan rendemen gula monomer yang tinggi, biaya yang lebih rendah, serta tidak menimbulkan korosi jika dibandingkan dengan hidrolisis dengan asam ataupun basa. Praperlakuan yang efektif dapat memudahkan proses selanjutnya karena membuat selulosa lebih mudah diakses oleh enzim dan meminimalkan pembentukan inhibitor yang menghambat pertumbuhan mikroorganisme saat fermentasi (Shen dkk., 2012). Praperlakuan dengan menggunakan asam encer mampu mendegradasi komponen hemiselulosa sehingga dapat membuka struktur selulosa untuk mempermudah proses enzimatis (Shi dkk., 2011). Beberapa asam organik seperti formiat, asetat, maleat, sitrat dan tartrat bisa menjadi praperlakuan alternatif untuk meningkatkan digestibilitas selulosa dikarenakan tingginya gula yang terbentuk (xilosa dan glukosa) dan rendahnya pembentukan furfural yang merupakan inhibitor ketika proses fermentasi (Qin dkk., 2012).

Lee dan Jeffries (2011) melakukan penelitian mengenai praperlakuan tongkol jagung dengan membandingkan 3 macam asam yaitu asam maleat, asam oksalat, dan asam sulfat. Hasil praperlakuan menunjukkan bahwa asam maleat dan asam oksalat mampu mendegradasi hemiselulosa lebih efektif dibandingkan dengan asam sulfat.

Praperlakuan dengan menggunakan reaktor bertekanan dilakukan oleh Jiang dkk. (2015) dengan biomassa dari batang kapas yang menghasilkan rendemen etanol sebesar 21,08 gr/100 gr biomassa. Dalam proses reaktor bertekanan, kelompok asetil pada hemiselulosa mampus dilepaskan untuk membentuk asam asetat yang dapat mempercepat degradasi hemiselulosa sehingga meningkatkan hidrolisis enzimatik.

Tujuan dari penelitian ini adalah untuk mengetahui pengaruh asam organik yaitu asam oksalat dan asam maleat, suhu dan waktu operasi terhadap produksi gula pereduksi dengan reaktor bertekanan pada tandan kosong kelapa sawit dengan melihat efisiensi dari praperlakuan ini antara lain terbentuknya senyawa coklat (brown compound), pulp yang dihasilkan, dan tingginya rendemen gula pereduksi setelah proses hidrolisis enzimatis. 


\section{METODE PENELITIAN \\ Bahan dan Alat}

Tandan kosong kelapa sawit yang berasal dari perkebunan kelapa sawit di Sukabumi, Jawa Barat. Bahan kimia yang digunakan merupakan bahan kimia untuk analisis dan mikrobiologi. Bahan kimia yang digunakan antara lain asam maleat 99\% (Merck) dan asam oksalat 99\% (Merck) untuk proses praperlakuan. Asam sitrat 99,5\% (Merck), sodium azida 99,5\% (Merck), enzim selulase (Meiji Seika Kaisha, Ltd, Jepang) untuk proses sakarifikasi serta sodium hidroksida 99\% (Merck), 3,5 asam dinitrosalicylic 98\% (Merck), sodium potassium tartrat 99\% (Merck), fenol 99\% (Merck), sodium metabisulfite 98\% (Merck) sebagai bahan pembuatan larutan DNS untuk uji gula pereduksi.

Alat yang digunakan untuk proses praperlakuan adalah reaktor bertekanan. Skema alat dapat dilihat pada Gambar 1.

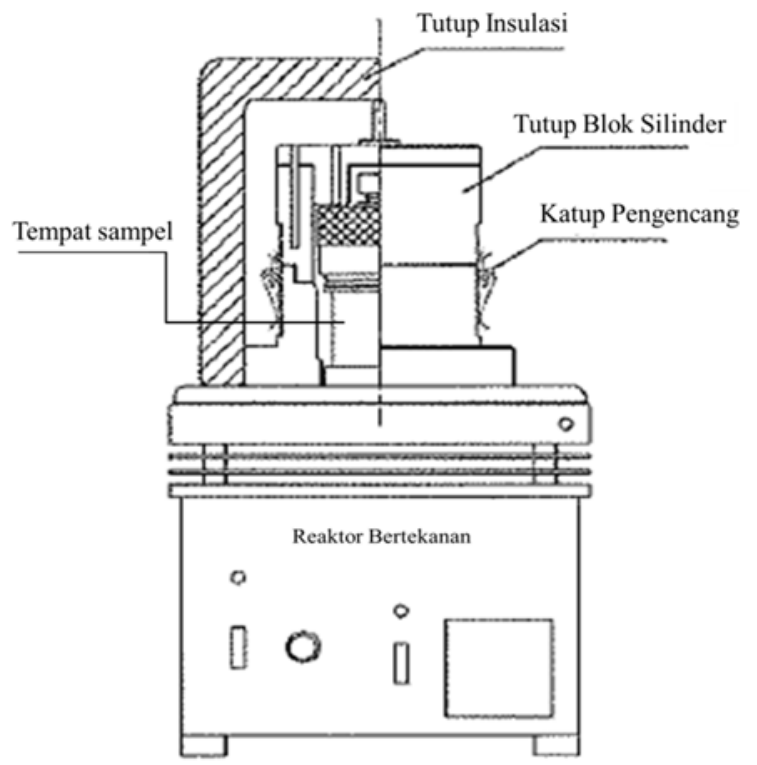

Gambar 1. Skema alat reaktor bertekanan

\section{Praperlakuan dengan Reaktor Bertekanan}

TKKS digiling dengan disc mill hingga diperoleh serbuk TKKS berukuran 40-60 mesh. Serbuk TKKS seberat 5 gr berat kering dilarutkan ke dalam 1\% $(\mathrm{w} / \mathrm{v})$ larutan asam organik. Larutan asam organik yang digunakan pada penelitian ini adalah asam oksalat dan asam maleat dengan perbandingan biomassa dan larutan sebesar 1:14 (w/v). Serbuk TKKS tersebut kemudian dipra-perlakuan dengan mengggunakan reaktor bertekanan yang sudah dipanaskan hingga mencapai suhu 170,180 , dan $190^{\circ} \mathrm{C}$ selama $15,30,45$, dan 60 menit dengan pengadukan. Setelah proses praperlakuan selesai, sampel didinginkan dengan menggunakan ice bath, lalu dipisahkan antara fase padat dan cairannya dengan penyaringan menggunakan kertas saring pada vacum jet pump.

\section{Pulp yang Dihasilkan dan Senyawa Coklat}

Fase padat (pulp) yang telah dipisahkan dinetralkan dengan menggunakan aquades hingga
pHnya 5-7 kemudian dipersiapkan untuk proses sakarifikasi yang terlebih dahulu dihitung kadar airnya untuk mengetahui berat kering pulp yang dihasilkan. Hidrolisat (fase cair) yang terbentuk di analisa dengan menggunakan spektrofotometer (UV VIS Hitachi U2001) pada panjang gelombang $490 \mathrm{~nm}$ untuk diukur konsentrasi senyawa coklat yang terbentuk (Warrand dan Janssen, 2007) dan diukur pHnya dengan menggunakan $\mathrm{pH}$ meter. Perhitungan \%pulp yang dihasilkan berdasarkan Persamaan 1.

Pulp yang dihasilkan (\%)

$=\frac{\text { berat kering sampel setelah proses praperlakuan }}{\text { berat kering sampel sebelum proses praperlakuan }} \times 100 \%$

\section{Sakarifikasi}

Proses sakarifikasi dilakukan berdasarkan metode standar prosedur analitis laboratorium dari US NREL (United States National Renewable Energy Laboratory) (Adney dan Baker, 2008). TKKS seberat 0,3 gr (berat kering) dari hasil praperlakuan disakarifikasi dengan campuran $6 \mathrm{ml}$ enzim meicelace (40 FPU/gr substrat), sodium azida $300 \mu \mathrm{l}(2 \% \mathrm{~m} / \mathrm{v})$, dan buffer sitrat $(50 \mathrm{mM})$ hingga mencapai total massa (berat) 30 gr. Sakarifikasi dilakukan dengan menggunakan incubator shaker pada suhu $50^{\circ} \mathrm{C}$ selama 48 jam dengan kecepatan $150 \mathrm{rpm}$.

\section{Metode Analisis \\ Kombinasi severity factor (SF)}

Severity factor (SF) merupakan faktor yang berfungsi untuk mengukur kesulitan pada saat proses praperlakuan yang mengkombinasikan suhu dan waktu reaksi serta konsentrasi asam menjadi satu variabel sebagai dasar untuk membandingkan efisiensi dari berbagai kondisi praperlakuan dan metode yang digunakan (Silverstein dkk., 2007; Lloyd dan Wyman, 2005). Rumus yang digunakan untuk menghitung severity factor pada penelitian ini adalah Persamaan 2 .

$$
\mathrm{SF}=\log \left\{\mathrm{t} \cdot \exp \left[\left(\mathrm{T}_{\mathrm{H}}-\mathrm{T}_{\mathrm{R}}\right) / 14,75\right]\right\}-\mathrm{pH}
$$

dimana t adalah waktu reaksi saat praperlakuan (menit), $\mathrm{T}_{\mathrm{H}}$ adalah suhu praperlakuan $\left({ }^{\circ} \mathrm{C}\right), \mathrm{T}_{\mathrm{R}}$ adalah suhu referensi $\left(100^{\circ} \mathrm{C}\right)$, dan $\mathrm{pH}$ adalah keasamaan dari larutan yang menunjukkan konsentrasi asam.

\section{Uji gula pereduksi}

Pengujian gula pereduksi dilakukan berdasarkan metode standar prosedur analitis laboratorium dari US NREL (United States National Renewable Energy Laboratory) dengan menggunakan larutan DNS (dinitrosalicylic acid) (Adney dan Baker, 2008). Cara pembuatan larutan DNS dengan mencampurkan air distilat sebanyak $1.416 \mathrm{ml}$ dengan asam 3,5 dinitrosalicylic sebanyak 10,6 gr dam sodium hidroksida sebanyak 19,8 gr. Setelah larut, dilanjutkan dengan menambahkan sodium potassium tartrat sebanyak 306 gr, fenol yang telah dilelehkan pada suhu $50^{\circ} \mathrm{C}$ sebanyak $7,6 \mathrm{ml}$ dan sodium metabisulfit sebanyak 8,3 gr hingga semuanya terlarut. 
Sampel cair sebanyak $2 \mathrm{ml}$ dari hasil sakarifikasi disentrifugasi untuk mendapatkan larutan supernatan. Larutan supernatant tersebut dianalisis total gula pereduksi dengan menggunakan spektrofotometer (UV VIS Hitachi U-2001) pada panjang gelombang $540 \mathrm{~nm}$. Rendemen gula pereduksi dihitung berdasarkan berat kering dari TKKS awal (substrat sebelum dipraperlakuan). Semua hasil penelitian ini dilakukan secara duplet dan data pada penelitian ini menunjukkan nilai rata-rata. Perhitungan rendemen gula pereduksi (\% substrat terhidrolisis) menggunakan Persamaan 3.

Rendemen gula pereduksi

$=\frac{\text { Total gula pereduksi (mg) }}{\text { Berat kering TKKS awal (g) }} \times 100 \%$

\section{HASIL DAN PEMBAHASAN \\ Pengaruh Praperlakuan Reaktor Bertekanan dan Asam Organik terhadap Recovery dari Pulp}

Gambar 2 dan 3 menunjukkan pengaruh kondisi operasi praperlakuan terhadap pulp yang dihasilkan. Dari grafik tersebut menunjukkan bahwa semakin lama waktu praperlakuan maka pulp yang dihasilkan akan semakin rendah. Pada asam oksalat dan asam maleat, pulp terendah yang dihasilkan masing-masing sebesar 55,79 dan $52,70 \%$ pada saat suhu $190^{\circ} \mathrm{C}$ dengan waktu praperlakuan selama 60 menit. Pulp tertinggi yang dihasilkan dengan menggunakan asam oksalat $(77,02 \%)$ tercapai pada suhu $170^{\circ} \mathrm{C}$ selama 15 menit praperlakuan. Hal ini berbeda dengan asam maleat, pulp tertinggi yang dihasilkan tercapai pada suhu $190^{\circ} \mathrm{C}$ sebesar $82,16 \%$ selama 15 menit praperlakuan.

Pulp yang dihasilkan menurun dengan semakin lamanya waktu pada saat praperlakuan. Rendahnya pulp yang dihasilkan tersebut menandakan bahwa proses praperlakuan telah mendegradasi hemiselulosa dari TKKS. Hemiselulosa lebih mudah didegradasi daripada lignin maupun selulosa. Hal ini dikarenakan derajat polimerisasi atau berat molekul hemiselulosa lebih rendah jika dibandingkan dengan lignin dan selulosa serta struktur dari hemiselulosa yang random, amorf, dan bercabang (Hermiati dkk., 2014). Hemiselulosa mulai mengalami degradasi pada suhu $180-340^{\circ} \mathrm{C}$ (Lv dkk., 2010). Selulosa akan terdegradasi pada suhu yang lebih tinggi antara $315-380^{\circ} \mathrm{C}$ karena komposisi selulosa yang berbentuk kristal dan amorf. Sedangkan lignin menjadi bagain yang paling sulit untuk terdekomposisi dengan suhu dekomposisi mencapai $900^{\circ} \mathrm{C}$ karena struktur dari lignin yang terdiri dari cincin aromatik dengan berbagai macam cabang. (Satimanont dkk., 2012).

Pada proses praperlakuan, hemiselulosa dihilangkan untuk memaksimalkan rendemen glukosa pada hidrolisat setelah proses hidrolisis enzimatis. Rendemen glukosa akan meningkat seiring dengan meningkatnya lama waktu proses praperlakuan. Hal ini dikarenakan hemiselulosa telah terdegradasi menjadi senyawa turunan selama proses praperlakuan dengan terbentukanya xilosa, manosa, asam asetat, galaktosa, dan glukosa. Pada suhu dan tekanan yang tinggi xilosa akan terdegradasi lagi menjadi furfural sedangkan manosa, galaktosa, dan glukosa akan terdegradasi menjadi senyawa hydroxymethylfurfural (HMF) (Palmqvist dan Hahn-Hägerdal, 2000; Satimanont dkk., 2012). Hemiselulosa yang telah terdegradasi selama proses praperlakuan akan larut pada saat pencucian pulp yang menyebabkan massa pulp yang dihasilkan lebih rendah.

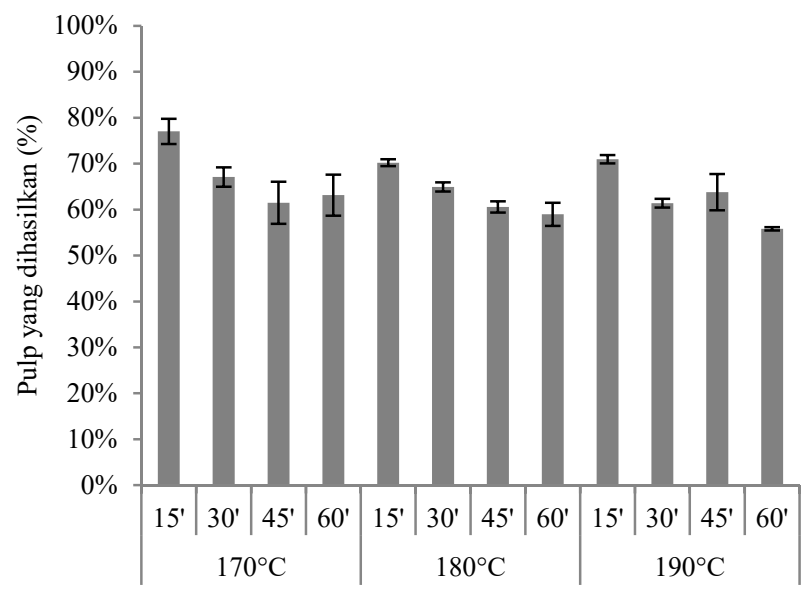

Gambar 2. Pulp yang dihasilkan dengan asam oksalat pada kondisi praperlakuan (waktu, suhu)

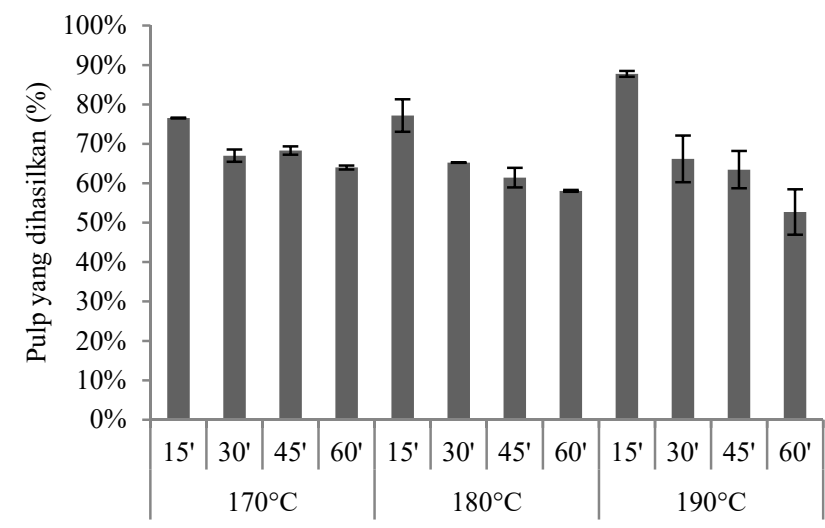

Gambar 3. Pulp yang dihasilkan dengan asam maleat pada kondisi praperlakuan (waktu, suhu)

\section{Pengaruh Praperlakuan Reaktor Bertekanan dan Asam Organik terhadap Pembentukan Senyawa Coklat}

Pembentukan senyawa coklat dalam hidrolisat mengindikasikan adanya modifikasi kimia yang terjadi pada gula pereduksi dan senyawa yang mengandung asam amino dan protein. Reaksi ini merupakan reaksi pencoklatan non enzimatis seperti reaksi Maillard dan karamelisasi yang disebabkan karena adanya pemanasan (Barclay dkk., 2012). Pada Gambar 4 dan 5 terlihat bahwa kondisi operasi saat praperlakuan berpengaruh terhadap pembentukan senyawa coklat.

Absorbansi senyawa coklat tertinggi pada asam oksalat saat praperlakuan (Gambar 4) dicapai pada suhu $170^{\circ} \mathrm{C}$ selama 60 menit yaitu sebesar 0,4125 , 
sedangkan pada asam maleat absorbansi tertinggi sebesar 0,405 pada suhu $190^{\circ} \mathrm{C}$ selama 60 menit (Gambar 5). Hal ini dikarenakan lamanya proses praperlakuan menyebabkan meningkatnya konsentrasi senyawa karbonil pada gula pereduksi TKKS, sehingga nantinya akan berpengaruh pada kandungan gula pereduksi setelah proses sakarifikasi. Pada praperlakuan dengan menggunakan asam maleat, terlihat bahwa pembentukan senyawa coklat cenderung meningkat seiring dengan meningkatnya waktu dan suhu praperlakuan. Hal ini disebabkan pada suhu $170^{\circ} \mathrm{C}$ hemiselulosa mulai mengalami degradasi menjadi xilosa dan dengan semakin meningkatnya suhu dan waktu praperlakuan, xilosa mengalami degradasi lebih jauh yang ditandai dengan adanya reaksi pencoklatan.

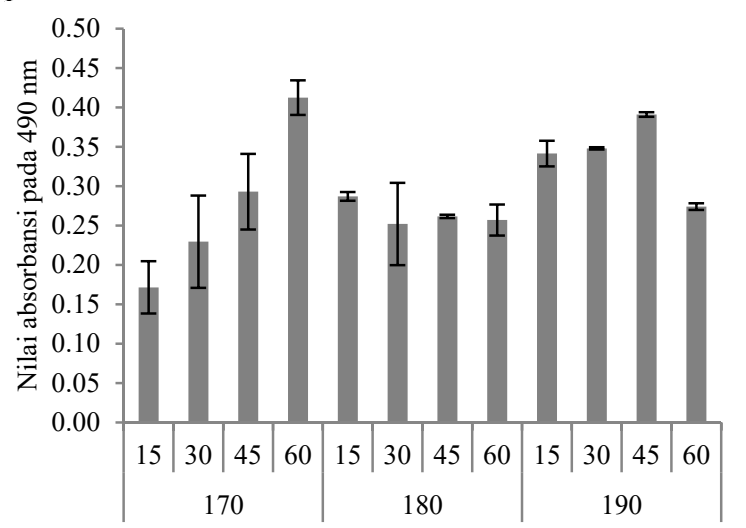

Gambar 4. Absorbansi senyawa coklat dengan asam oksalat pada kondisi praperlakuan (waktu, suhu, dan

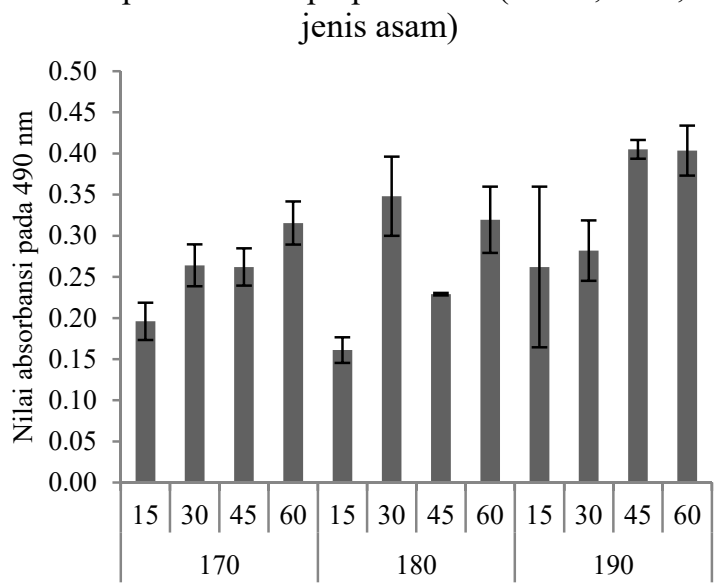

Gambar 5. Absorbansi senyawa coklat dengan asam maleat pada kondisi praperlakuan (waktu, suhu, dan jenis asam)

\section{Hasil Rendemen Gula Pereduksi}

Praperlakuan dengan menggunakan asam efektif dalam mendegradasi hemiselulosa menjadi gula terlarut dan meningkatkan rendemen glukosa dari selulosa hingga $100 \%$ yang disebabkan karena hemiselulosa yang terdegradasi pada saat hidrolisis. Hemiselulosa akan terdegradasi ketika ditambahkan asam sehingga meningkatkan digestibilitas selulosa pada fase padatan residu (Mosier dkk., 2002). Suhu yang tinggi pada saat praperlakuan dengan menggunakan asam sangat baik untuk hidrolisis selulosa (McMillan dan James, 1994).

Pada Gambar 6 menunjukkan rendemen gula pereduksi mencapai maksimum $(80,84 \%$ dari biomassa awal) setelah dilakukan praperlakuan dengan menggunakan asam maleat pada suhu $170^{\circ} \mathrm{C}$ selama 60 menit, sedangkan dengan menggunakan asam oksalat (Gambar 7) pada suhu $170^{\circ} \mathrm{C}$ selama 60 menit didapatkan rendemen sebesar $45,77 \%$ dari biomassa awal. Rendemen yang didapatkan pada kedua jenis asam berbeda cukup jauh. Asam maleat menghasilkan rendemen gula jauh lebih tinggi, hal ini dikarenakan $\mathrm{pKa}$ dari asam maleat yang lebih tinggi $\left(\mathrm{pK}_{\mathrm{a} 1}=1,94\right.$, $\mathrm{pK}_{\mathrm{a} 2}=6,22$ ) (National Center for Biotechnology Information $^{\mathrm{a}}$ ) jika dibandingkan dengan asam oksalat $\left(\mathrm{pK}_{\mathrm{a} 1}=1,46, \quad \mathrm{pK}_{\mathrm{a} 2}=4,40\right) \quad$ (National Center for Biotechnology Information ${ }^{\mathrm{b}}$ ) yang menyebabkan proses hidrolisis menjadi lebih efisien dengan rentang suhu dan waktu yang sama (Mosier dkk., 2002).

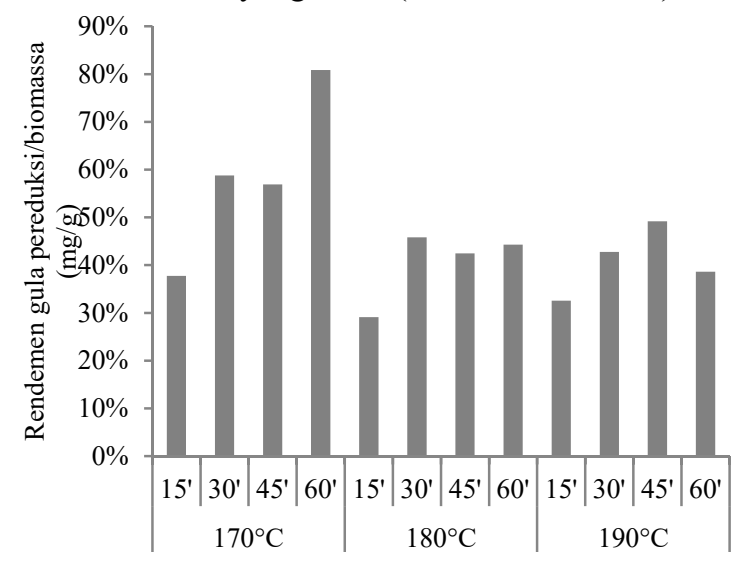

Gambar 6. Rendemen gula pereduksi/biomassa awal dengan asam maleat pada setiap kondisi praperlakuan (waktu, suhu)

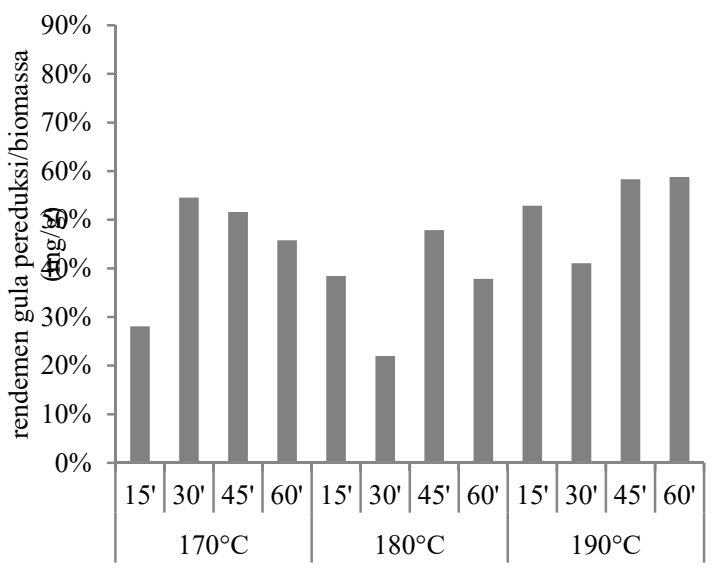

Gambar 7. Rendemen gula pereduksi/biomassa awal dengan asam oksalat pada setiap kondisi praperlakuan waktu dan suhu

Asam maleat merupakan asam karboksilat yang tidak mengkatalis degradasi glukosa. Degradasi glukosa yang terdapat pada larutan asam karboksilat 
terjadi karena mekanisme yang sama dan pada kecepatan yang sama dengan yang terjadi pada air. Hasil ini menunjukkan tingginya selektivitas asam maleat pada proses sakarifikasi selulosa (Mosier dkk., 2002). Rendemen gula pereduksi pada asam maleat mengalami penurunan pada saat praperlakuan suhu $180^{\circ} \mathrm{C}$ dan $190^{\circ} \mathrm{C}$. Penurunan gula pereduksi pada suhu dan waktu yang lebih tinggi terjadi karena sebagian gula pereduksi yang terbentuk terdegradasi lebih lanjut menjadi senyawa dengan berat molekul lebih rendah, seperti furfural, HMF, asam levunilik dan asam format (Palmqvist dan Hahn-Hägerdal, 2000) yang ditandai dengan meningkatnya absorbansi senyawa coklat yang dihasilkan.

\section{Pengaruh Severity Factor (SF) terhadap Rendemen Gula Pereduksi}

Pengaruh SF pada rendemen gula pereduksi dengan menggunakan reaktor bertekanan terlihat pada Gambar 8 dan 9. Pada Gambar 8, praperlakuan dengan asam maleat, memperlihatkan bahwa rendemen gula $>$ $50 \%$ berada pada rentang SF $1,62-1,84$. SF di atas 1,84 cenderung tidak memiliki perbedaan yang signifikan pada rendemen gula pereduksi. Jika dilihat pada tabel 1 , SF dengan rentang $1,6-1,8$ terjadi pada suhu $170^{\circ} \mathrm{C}$. Sedangkan pada Gambar 9, SF pada praperlakuan dengan menggunakan asam oksalat menghasilkan rendemen gula pereduksi $>50 \%$ pada rentang $2,0-2,1$. SF pada rentang tersebut terjadi pada suhu $190^{\circ} \mathrm{C}$ (Tabel 1).

Pada perlakuan dengan menggunakan asam maleat, gula pereduksi mengalami kenaikan yang signifikan pada SF 1,6-1,8 dari 37.75 hingga $80.84 \%$ sedangkan pada SF di atas 1,8 , produksi gula pereduksi mengalami penurunan. Peningkatan gula pereduksi

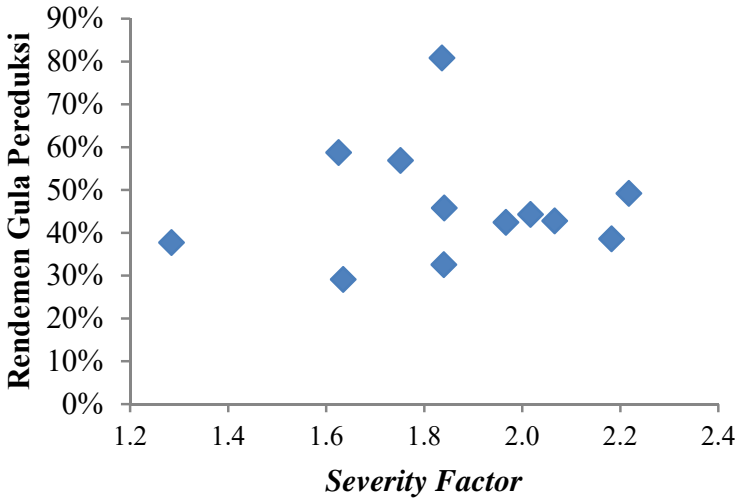

Gambar 8. Grafik hubungan antara rendemen gula pereduksi/biomassa awal dan severity factor dengan menggunakan asam maleat

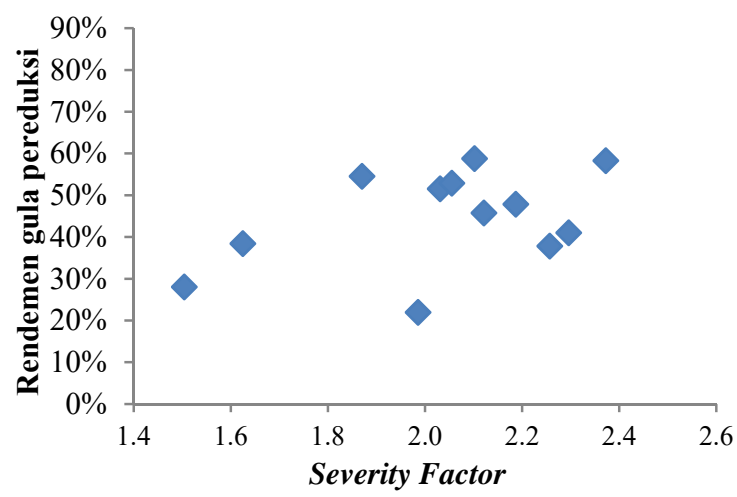

Gambar 9. Grafik hubungan antara rendemen gula pereduksi/biomassa awal dan severity factor dengan menggunakan asam oksalat

Tabel 1. Pengaruh severity factor terhadap rendemen gula pereduksi pada setiap kondisi praperlakuan

\begin{tabular}{|c|c|c|c|c|}
\hline Asam & Suhu & Waktu & Severity factor & $\begin{array}{c}\text { Rendemen gula pereduki/ } \\
\text { Biomassa }(\mathrm{mg} / \mathrm{g})\end{array}$ \\
\hline \multirow{12}{*}{ Asam Oksalat } & $170^{\circ} \mathrm{C}$ & $15^{\prime}$ & 1,504 & $28,08 \%$ \\
\hline & & $30^{\prime}$ & 1,870 & $54,56 \%$ \\
\hline & & $45^{\prime}$ & 2,031 & $51,58 \%$ \\
\hline & & $60^{\prime}$ & 2,121 & $45,77 \%$ \\
\hline & $180^{\circ} \mathrm{C}$ & $15^{\prime}$ & 1,625 & $38,44 \%$ \\
\hline & & $30^{\prime}$ & 1,986 & $21,97 \%$ \\
\hline & & $45^{\prime}$ & 2,187 & $47,88 \%$ \\
\hline & & $60^{\prime}$ & 2,257 & $37,84 \%$ \\
\hline & $190^{\circ} \mathrm{C}$ & $15^{\prime}$ & 2,055 & $52,89 \%$ \\
\hline & & $30^{\prime}$ & 2,296 & $41,05 \%$ \\
\hline & & $45^{\prime}$ & 2,372 & $58,31 \%$ \\
\hline & & $60^{\prime}$ & 2,102 & $58,81 \%$ \\
\hline \multirow{12}{*}{ Asam Maleat } & $170^{\circ} \mathrm{C}$ & $15^{\prime}$ & 1,284 & $37,75 \%$ \\
\hline & & $30^{\prime}$ & 1,625 & $58,77 \%$ \\
\hline & & $45^{\prime}$ & 1,751 & $56,89 \%$ \\
\hline & & $60^{\prime}$ & 1,836 & $80,84 \%$ \\
\hline & $180^{\circ} \mathrm{C}$ & $15^{\prime}$ & 1,635 & $29,13 \%$ \\
\hline & & $30^{\prime}$ & 1,841 & $45,83 \%$ \\
\hline & & $45^{\prime}$ & 1,967 & $42,45 \%$ \\
\hline & & $60^{\prime}$ & 2,017 & $44,30 \%$ \\
\hline & $190^{\circ} \mathrm{C}$ & $15^{\prime}$ & 1,840 & $32,58 \%$ \\
\hline & & $30^{\prime}$ & 2,066 & $42,79 \%$ \\
\hline & & $45^{\prime}$ & 2,217 & $49,20 \%$ \\
\hline & & $60^{\prime}$ & 2,182 & $38,62 \%$ \\
\hline
\end{tabular}


dikarenakan hemiselulosa mulai terdegradasi menjadi xilosa dan gula pereduksi yang lain pada suhu $170^{\circ} \mathrm{C}$. Pada SF diatas 1,8 dengan suhu yang meningkat produksi gula pereduksi mengalami penurunan karena xilosa yang terbentuk mengalami degradasi lebih lanjut menjadi fufural dan HMF (Lee dan Jeffries, 2011). Produksi gula pereduksi mengalami peningkatan pada praperlakuan dengan menggunakan asam oksalat dengan SF 1,4 hingga 2,1. Sedangkan gula pereduksi mengalami penurunan pada SF diatas 2,1. Asam oksalat dan asam maleat merupakan asam organik kuat, adanya sifat dikarboksilat membuat kedua asam tersebut memiliki seletivitas yang tinggi untuk menghidrolisis hemiseulosa (Mosier dkk., 2002; Lu dan Mosier, 2007). Perbedaan SF pada asam maleat dan asam oksalat terjadi karena kemampuan katalis biomimetik yang dimiliki oleh asam maleat dari asam dikarboksilat pada asam maleat lebih tinggi dibandingkan dengan asam oksalat.

Residu selulosa dan produk yang terbentuk selama proses praperlakuan bervariasi tergantung pada waktu dan suhu praperlakuan yang digunakan. Suhu yang tinggi dan waktu praperlakuan yang lama menghidrolisis hemiselulosa lebih banyak untuk memproduksi gula pereduksi. Jumlah gula pereduksi lebih sedikit ketika waktu praperlakuan yang lebih singkat dan suhu yang lebih rendah (Satimanont dkk., 2012). Kuantitas gula pereduksi mengalami penurunan pada suhu yang tinggi dan waktu yang lama dikarenakan degradasi xilosa, manosa, galaktosa, dan glukosa menjadi furfural dan HMF semakin meningkat (Palmqvist and Hahn-Hägerdal, 2000). Kim dkk. (2014) melakukan penelitian dengan menggunakan makro alga sebagai sumber biomassa dengan suhu praperlakuan $130-210^{\circ} \mathrm{C}$ selama 30 dan 60 menit. Pada penelitian tersebut produksi gula pereduksi, semakin meningkat dari suhu $130-170^{\circ} \mathrm{C}$ dan mulai mengalami penurunan yang signifikan pada suhu $190^{\circ} \mathrm{C}$ dengan waktu praperlakuan selama 60 menit. Praperlakuan selama 30 menit, produksi gula pereduksi mengalami peningkatan hingga suhu $190^{\circ} \mathrm{C}$ dan menurun drastis pada suhu $210^{\circ} \mathrm{C}$.

Severity factor dipengaruhi oleh suhu dan waktu praperlakuan. Tingginya suhu dan lamanya waktu akan menyebabkan severity factor yang tinggi. Pada Tabel 1, rendemen gula pereduksi pada praperlakuan asam oksalat tertinggi $(58,81 \%)$ dicapai pada $S F 2,102$ sedangkan pada asam maleat, rendemen gula pereduksi tertinggi $(80,84 \%)$ dicapai pada $S F$ sebesar 1,836. Jika dilihat dari energi yang dibutuhkan, maka $S F$ yang lebih tinggi memerlukan energi yang lebih besar. Pada asam oksalat, rendemen gula pereduksi tertinggi tercapai pada suhu $190^{\circ} \mathrm{C}$ sedangkan pada asam maleat tercapai pada suhu $170^{\circ} \mathrm{C}$, hal ini mengakibatkan energi yang digunakan untuk praperlakuan dengan menggunakan asam oksalat lebih tinggi jika dibandingkan dengan asam maleat. Tidak hanya kebutuhan energi yang besar pada praperlakuan dengan asam oksalat, hasil rendemennya pun berbeda jauh lebih rendah jika dibandingkan dengan asam maleat.

\section{KESIMPULAN}

Praperlakuan dengan menggunakan asam maleat menunjukkan hasil yang lebih baik dengan severity factor yang lebih rendah jika dibandingkan dengan menggunakan asam oksalat. Secara umum hal ini ditandai dengan pulp yang dihasilkan pada asam maleat yang lebih tinggi dan rendemen gula pereduksi yang lebih tinggi jika dibandingkan dengan asam oksalat. Rendemen gula pereduksi optimum sebesar $80,84 \%$ dengan menggunakan asam maleat pada suhu $170^{\circ} \mathrm{C}$ selama 60 menit, dan severity factor 1,836 . Asam maleat memiliki pKa yang lebih tinggi yang menyebabkan proses hidrolisis menjadi lebih efisien dan juga didukung dengan rendahnya severity factor menyebabkan kebutuhan energi semakin kecil.

\section{UCAPAN TERIMA KASIH}

Penulis mengucapkan terimakasih kepada Pusat Penelitian Biomaterial Lembaga Ilmu Pengetahuan Indonesia (LIPI) yang sudah menyediakan dana untuk melakukan penelitian ini melalui Program DIPA 2015 dan juga berterimakasih atas dukungan dari JST-JICASatreps yang telah memberikan bantuan peralatan sehingga penelitian ini dapat terlaksana.

\section{DAFTAR PUSTAKA}

Adney, B. and Baker, J. (2008). Measurement of Cellulase Activities: Laboratory Analytical Procedure (LAP), National Renewable Energy Laboratory. Technical Report.

Barclay, T., Ginic-Markovic, M., Cooper, P.D., and Petrovsky, N. (2012). The Chemistry and Sources of Fructose and Their Effect on Its Utility and Health Implications, $P h D$ Thesis, International Pharmaceutical Excipients Council, Americas.

Direktorat Jenderal Perkebunan, (2016), Luas Areal, Produksi dan Produktivitas Perkebunan Di Indonesia, http://www.pertanian.go.id/Indikator/tabel-3-prodlsareal-prodvitas-bun.pdf, diakses 5 Februari 2016.

Hendriks, A.T.W.M. and Zeeman, G. (2009), Pretreatments to Enhance the Digestibility of Lignocellulosic Biomass, Bioresource Technology, 100(1), pp. 10-18.

Hermiati, E., Risanto, L., Anita, S.H., Aristiawan, Y., dan Sudiyani, Y. (2014), Sakarifikasi Serat Tandan Kosong dan Pelepah Kelapa Sawit setelah Pretreatment Menggunakan Kultur Campuran Jamur Pelapuk Putih Phanerochaete chrysosporium dan Trametes versicolor, Jurnal Penelitian Hasil Hutan, 32(2), hal. 111-122.

Jiang, W., Chang, S., Li, H., Oleskowicz-Popiel, P., and $\mathrm{Xu}$, J., (2015), Liquid Hot Water Pretreatment on Different Parts of Cotton Stalk to Facilitate Ethanol Production, Bioresource Technology, 176, pp. 175-180. 
Kerdsuwan, S. and Laohalidanond, K., (2011), Renewable Energy from Palm Oil Empty Fruit Bunch, INTECH Open Access Publisher.

Kim, D.H., Lee, S.B., and Jeong, G.T., (2014), Production of Reducing Sugar from Enteromorpha Intestinalis by Hydrothermal and Enzymatic Hydrolysis, Bioresource Technology, 161, pp. 348-353.

Kim, S. and Dale, B.E. (2004), Global Potential Bioethanol Production from Wasted Crops and Crop Residues, Biomass and Bioenergy, 26(4), pp. 361-375.

Lee, J.W. and Jeffries, T.W. (2011), Efficiencies of Acid Catalysts in the Hydrolysis of Lignocellulosic Biomass over a Range of Combined Severity Factors, Bioresource Technology, 102(10), pp. 5884-5890.

Lloyd, T.A. and Wyman, C.E. (2005), Combined Sugar Yields for Dilute Sulfuric Acid Pretreatment of Corn Stover Followed by Enzymatic Hydrolysis of The Remaining Solids, Bioresource Technology, 96(18), pp. 1967-1977.

Lu, Y. and Mosier, N. S. (2007), Biomimetic Catalysis for Hemicellulose Hydrolysis in Corn Stover, Biotechnology Progress, 23(1), pp. 116-123.

Lv, G.J., Wu, S.B., and Lou, R. (2010), Kinetic Study for The Thermal Decomposition of Hemicellulose Isolated from Corn Stalk, BioResources, 5(2), pp. 1281-1291.

Mcmillan, and James D., (1994), Pretreatment of Lignocellulosic Biomass, Enzymatic Conversion of Biomass for Fuels Production, Chapter 15, pp. 292324

Mohammad, N., Alam, M.Z., Kabbashi, N.A., and Ahsan, A., (2012), Effective Composting of Oil Palm Industrial Waste by Filamentous Fungi: A Review, Resources, Conservation and Recycling, 58, pp. 69-78.

Mosier, N.S., Ladisch, C.M., and Ladisch, M.R. (2002), Characterization of Acid Catalytic Domains for Cellulose Hydrolysis and Glucose Degradation, Biotechnology and Bioengineering, 79(6), 610-618.

National Center for Biotechnology Information ${ }^{\mathrm{a}}$. PubChem Compound Database; CID $=444266$, https://pubchem.ncbi.nlm.nih.gov/compound/444266 (accessed Feb. 1, 2017).

National Center for Biotechnology Information ${ }^{b}$. PubChem Compound Database; CID $=971$, https://pubchem.ncbi.nlm.nih.gov/compound/971 (accessed Feb. 1, 2017).

Palmqvist, E. and Hahn-Hägerdal, B. (2000), Fermentation of Lignocellulosic Hydrolysates II: Inhibitors and Mechanisms of Inhibition, Bioresource Technology, 74(1), pp. 25-33.
Pu, Y., Hu, F., Huang, F., Davison, B.H., and Ragauskas, A.J. (2013), Assessing the Molecular Structure Basis for Biomass Recalcitrance during Dilute Acid and Hydrothermal Pretreatments, Biotechnology for Biofuels, 6(1), p. 15.

Qin, L., Liu, Z.H., Li, B.Z., Dale, B.E., and Yuan, Y.J., (2012), Mass Balance and Transformation of Corn Stover by Pretreatment with Different Dilute Organic Acids, Bioresource Technology, 112, pp. 319-326.

Sarkar, N., Ghosh, S.K., Bannerjee, S., and Aikat, K. (2012), Bioethanol Production from Agricultural Wastes: An Overview, Renewable Energy, 37(1), pp. 19-27.

Satimanont, S., Luengnaruemitchai, A., and Wongkasemjit, S. (2012), Effect of Temperature and Time on Dilute Acid Pretreatment of Corn Cobs, International Journal Chemical Biological Engineering, 6, pp. 333-337.

Shen, F., Hu, J., Zhong, Y., Liu, M. L., Saddler, J.N., and Liu, R. (2012), Ethanol Production from SteamPretreated Sweet Sorghum Bagasse with High Substrate Consistency Enzymatic Hydrolysis, Biomass and Bioenergy, 41, pp. 157-164.

Shi, J., Ebrik, M. A., and Wyman, C.E. (2011), Sugar Yields from Dilute Sulfuric Acid and Sulfur Dioxide Pretreatments and Subsequent Enzymatic Hydrolysis of Switchgrass, Bioresource Technology, 102(19), pp. 8930-8938.

Silverstein, R.A., Chen, Y., Sharma-Shivappa, R.R., Boyette, M.D., and Osborne, J., (2007), A Comparison of Chemical Pretreatment Methods for Improving Saccharification of Cotton Stalks, Bioresource Technology, 98(16), pp. 3000-3011.

Talebnia, F., Karakashev, D., and Angelidaki, I. (2010), Production of Bioethanol from Wheat Straw: an Overview on Pretreatment, Hydrolysis and Fermentation, Bioresource Technology, 101(13), pp. $4744-4753$

Wang, M., Wu, M., and Huo, H. (2007), Life-cycle Energy and Greenhouse Gas Emission Impacts of Different Corn Ethanol Plant Types, Environmental Research Letters, 2(2), pp. 1-13.

Warrand, J. and Janssen, H.G., (2007). Controlled Production of Oligosaccharides from Amylose by Acid-Hydrolysis under Microwave Treatment: Comparison with Conventional Heating, Carbohydrate Polymers, 69(2), pp. 353-362.

Yusoff, S. (2006), Renewable Energy from Palm OilInnovation on Effective Utilization of Waste, Journal of Cleaner Production, 14(1), pp. 87-93. 